University of New Hampshire

University of New Hampshire Scholars' Repository

$11-16-2007$

\title{
A summer time series of particulate carbon in the air and snow at Summit, Greenland
}

Gayle S.W. Hagler

Georgia Institute of Technology - Main Campus

M Bergin

Georgia Institute of Technology - Main Campus

Eugene A. Smith

Georgia Institute of Technology - Main Campus

Jack E. Dibb

University of New Hampshire, jack.dibb@unh.edu

Follow this and additional works at: https://scholars.unh.edu/earthsci_facpub

Part of the Atmospheric Sciences Commons

\section{Recommended Citation}

Hagler, G. S. W., M. H. Bergin, E. A. Smith, and J. E. Dibb (2007), A summer time series of particulate carbon in the air and snow at Summit, Greenland, J. Geophys. Res., 112, D21309, doi:10.1029/ 2007JD008993.

This Article is brought to you for free and open access by the Earth Sciences at University of New Hampshire Scholars' Repository. It has been accepted for inclusion in Earth Sciences Scholarship by an authorized administrator of University of New Hampshire Scholars' Repository. For more information, please contact Scholarly.Communication@unh.edu. 


\title{
A summer time series of particulate carbon in the air and snow at Summit, Greenland
}

\author{
Gayle S. W. Hagler, ${ }^{1}$ Michael H. Bergin, ${ }^{1,2}$ Eugene A. Smith, ${ }^{1}$ and Jack E. Dibb ${ }^{3}$ \\ Received 21 May 2007; revised 22 July 2007; accepted 14 August 2007; published 10 November 2007.
}

[1] Carbonaceous particulate matter is ubiquitous in the lower atmosphere, produced by natural and anthropogenic sources and transported to distant regions, including the pristine and climate-sensitive Greenland Ice Sheet. During the summer of 2006, ambient particulate carbonaceous compounds were characterized on the Greenland Ice Sheet, including the measurement of particulate organic (OC) and elemental (EC) carbon, particulate water-soluble organic carbon (WSOC), particulate absorption coefficient ( $\left.\sigma_{\text {ap }}\right)$, and particle size-resolved number concentration $\left(\mathrm{PM}_{0.1-1.0}\right)$. Additionally, parallel $\sim 50$-day time series of water-soluble organic carbon (WSOC), water-insoluble organic carbon (WIOC), and elemental carbon (EC) were quantified at time increments of 4-24 h in the surface snow. Measurement of atmospheric particulate carbon found WSOC (average of $52 \mathrm{ng} \mathrm{m}^{-3}$ ) to constitute a major fraction of particulate OC (average of $56 \mathrm{ng}$ $\mathrm{m}^{-3}$ ), suggesting that atmospheric organic compounds reaching the Greenland Ice Sheet in summer are highly oxidized. Atmospheric EC (average of $7 \mathrm{ng} \mathrm{m}^{-3}$ ) was wellcorrelated with $\sigma_{\text {ap }}(\mathrm{r}=0.95)$ and the calculated mass-absorption cross-section (average of $24 \mathrm{~m}^{2} \mathrm{~g}^{-1}$ ) appears to be similar to that measured using identical techniques in an urban environment in the United States. Comparing surface snow to atmospheric particulate matter concentrations, it appears the snow has a much higher OC (WSOC+WIOC) to EC ratio (205:1) than air (10:1), suggesting that snow is additionally influenced by watersoluble gas-phase compounds. Finally, the higher-frequency (every 4-6 h) sampling of snow-phase WSOC revealed significant loss (40-54\%) of related organic compounds in surface snow within $8 \mathrm{~h}$ of wet deposition.

Citation: Hagler, G. S. W., M. H. Bergin, E. A. Smith, and J. E. Dibb (2007), A summer time series of particulate carbon in the air and snow at Summit, Greenland, J. Geophys. Res., 112, D21309, doi:10.1029/2007JD008993.

\section{Introduction}

[2] Carbonaceous aerosols, broadly defined in two fractions as organic carbon (OC) and elemental carbon (EC), are receiving heightened interest for their ability to act as tracers of anthropogenic and natural emissions. In particular, past research has found that the ambient particulate organic fraction contains numerous compounds, many of which are stable in the atmosphere and can fingerprint source types such as biomass burning, coal combustion, and vehicular transport [Schauer et al., 1996; Simoneit et al., 1999]. Elemental carbon can also act as a tracer of combustion emissions and is often used as an indicator of primary carbon, with high $\mathrm{OC} / \mathrm{EC}$ ratios marking the

\footnotetext{
${ }^{1}$ School of Civil and Environmental Engineering, Georgia Institute of Technology, Atlanta, Georgia, USA.

${ }^{2}$ School of Earth and Atmospheric Sciences, Georgia Institute of Technology, Atlanta, Georgia, USA

${ }^{3}$ Climate Change Research Center, Institute for the Study of Earth, Oceans, and Space, University of New Hampshire, Durham, New Hampshire, USA.
}

Copyright 2007 by the American Geophysical Union. 0148-0227/07/2007JD008993 formation of secondary organic carbon in the atmosphere [Lim and Turpin, 2002].

[3] Outside of its utility as a combustion tracer, EC is of special interest in polar regions for its ability to act as a warming influence in the air, and after deposition to surface snow. Derived from fossil fuel combustion and biomass burning emissions, EC is closely related to black carbon (BC), which is generally defined as light-absorbing carbon mass. Since the mid-1980s, BC entrapped in snow has been highlighted for its potential to lower surface snow albedo and contribute to local warming in snow covered regions [Clarke and Noone, 1985; Twohy et al., 1989; Warren and Wiscomb, 1985]. While the Greenland Ice Sheet has been reported to be warming at an accelerated pace of 2.2 times the global temperature increase over the time period of 1974-2005 [Chylek and Lohmann, 2005], it is uncertain to what degree $\mathrm{BC}$ plays a role in local warming. Recent modeling efforts have found the Arctic climate to be particularly sensitive to $\mathrm{BC}$ due to the surface albedo feedback mechanism, although the exact magnitude of the impact is debated [Hansen and Nazarenko, 2004; Roberts and Jones, 2004]. On the other hand, looking specifically at the Greenland Ice Sheet, BC concentrations in the Greenland snowpack have been found to be much lower than 
elsewhere in the Arctic and thus may actually have only a small local warming influence [Clarke and Noone, 1985]. However, information on the temporal variability of $\mathrm{BC}$ in the surface snow on the Greenland Ice Sheet is needed to understand the extent to which BC can modify local climate.

[4] While gas-phase organics have been measured in numerous field studies on the Greenland Ice Sheet [Dassau et al., 2002; Dibb and Arsenault, 2002; Dibb et al., 1994; Ford et al., 2002; Hutterli et al., 1999; Jacobi et al., 2002], fewer measurements of atmospheric particulate carbon compounds have been reported. Specific organic compounds, including PAHs [Jaffrezo et al., 1993] and particulate oxalate [Jaffrezo et al., 1998; Kerminen et al., 1998], have been measured at Summit, Greenland (the highest point of the Greenland Ice Sheet). In addition, major biomass burning episodes impacting the air above the Greenland Ice Sheet were detected through atmospheric measurements of oxalate [Jaffrezo et al., 1998], ${ }^{14} \mathrm{C}$ [Currie et al., 2005], and black carbon [Stohl et al., 2006]. To our knowledge, there are no other reported measurements of particulate carbonaceous species in the Greenland atmosphere. The limited information on atmospheric carbonaceous particulate matter on the Greenland Ice Sheet underlines the need for further research.

[5] In addition to the interest in carbonaceous particulate matter present in the Greenland atmosphere, the deposition of OC and EC to snow can serve as a historical snow and ice record of anthropogenic and natural emissions. However, as pointed out in our recent paper discussing the OC and EC record in a 3-m snow pit on the Greenland Ice Sheet [Hagler et al., 2007], it appears that snow-phase OC may undergo substantial post-depositional processing. Other researchers have also found an indication of OC loss from snow through the enhancement of organic gases in or above the snowpack [Dibb and Arsenault, 2002; Jacobi et al., 2004; Swanson et al., 2002; Anderson et al., unpublished results]. While EC is likely stable after deposition to snow, it appears that we must progress with caution toward using organic compounds as historical tracers.

[6] This paper complements and expands upon our earlier analysis [Hagler et al., 2007] by providing a summer-long record of atmospheric and snow-phase particulate matter concentrations at Summit, Greenland. Results include atmospheric measurements of particulate elemental carbon (EC), particulate organic carbon (OC), and, along with our colleagues from the University of New Hampshire (Anderson et al., unpublished results), particulate water-soluble organic carbon (WSOC) on the Greenland Ice Sheet. Additionally, the climate-relevant measurement of the particulate absorption coefficient $\left(\sigma_{\text {ap }}\right)$ is provided. To better understand the linkage between the air and snow record of carbonaceous species, deposition events and the comparison of air and snow concentrations are presented and discussed.

\section{Methods}

[7] Atmospheric and snow-phase particulate matter measurements were conducted for $\sim 50$ days during the summer season at Summit, Greenland. Summit is a National Science Foundation research site located at the highest point of the Greenland Ice Sheet ( $3200 \mathrm{~m}$ in elevation). Given that the target of this research was to quantify extremely low carbonaceous particulate matter concentrations, strict attention was paid to avoid contamination due to camp emissions. All sampling was conducted at a satellite location in the designated "clean air sector" approximately $1 \mathrm{~km}$ from base camp activities, with camp emissions (i.e., use of heavy equipment and snowmobiles) reduced when wind directions would cause plumes to travel toward the clean air region. However, the use of a diesel generator to provide camp electricity and infrequent plane traffic were not regulated by wind direction and posed a potential contamination threat. To protect multiday filter collection from camp emissions, a sector control system was put in place to halt collection during stagnant conditions (wind speed $<$ $0.5 \mathrm{~m} \mathrm{~s}^{-1}$ ) or during wind directions covering camp emission locations. In addition, filter collection was manually stopped during aircraft arrival and departure. For near real-time atmospheric measurements, the sector control data was used to later filter out time periods of possible contamination.

[8] Integrated atmospheric samples for the measurement of carbonaceous particulate matter (OC, WSOC, EC) were collected on two side-by-side $25 \mathrm{~mm}$ quartz fiber filters (Pall Corp: \#2500 QAT-UP, $25 \mathrm{~mm}$ ) in stainless steel filter holders (Pall Corp: \#1209). Prior to use in sampling, filters were heated to $550^{\circ} \mathrm{C}$ for $12 \mathrm{~h}$, sealed in Petri dishes lined with pre-fired aluminum, and were loaded into filter holders under a clean hood at the field site. Each sample set was collected for $\sim 80 \mathrm{~h}$, with sampling interruption due to sector control leading to total sample set durations ranging 4-7 days depending on wind patterns. Each flow line operated at a mass flow rate of $18.1 \mathrm{lpm}$ (set by critical orifices) downstream of $16.7 \mathrm{lpm} \mathrm{PM}_{2.5}$ cyclones (URG Corp., \#URG-2000-30EH), yielding an approximate $2.3 \mu \mathrm{m}$ $\mathrm{D}_{50}$ size cut. A major motivation to include cyclones upstream of the filters was to avoid sampling fog droplets, an occurrence which caused visible ice build-up on the filter samples during a previous field season. As no ice was observed on samples during the 2006 study, it appears that the cyclones effectively prevented any sampling of fog. Flow rates were periodically measured using a NIST-traceable dry gas meter (ID \#C-0701). Field blanks were taken by loading a sample filter into a filter holder, unloading, and analyzing alongside the ambient samples. After collection, filter samples were kept at below-freezing temperatures and later analyzed for OC, EC, and WSOC at the Georgia Institute of Technology. OC and EC were detected using the NIOSH thermal/optical transmittance (TOT) method [Birch and Cary, 1996]. For atmospheric samples with such low concentrations that one filter punch (area of $1 \mathrm{~cm}^{2}$ ) had barely detectable carbon mass, two filter punches were overlaid to achieve detection. Prior laboratory tests were performed on 3 sets of co-located filter samples at concentrations similar to that of the Greenland samples. It was found that the agreement between single and layered filters was 7\% for OC and $21 \%$ for EC, with no systematic upper or lower bias. WSOC was extracted from the filters by placing a filter punch into a pre-fired glass vial filled with $10 \mathrm{~mL}$ of ultrapure deionized water and agitating for $40 \mathrm{~min}$ in an ultrasonic bath. In cases where only one filter punch was required to detect $\mathrm{OC}$ and $\mathrm{EC}$, duplicates of all carbonaceous species (OC, EC, and WSOC) were processed. However, when two filter punches were needed for $\mathrm{OC}$ 
Table 1. Measured Atmospheric Species at Summit, Greenland During Summer 2006

\begin{tabular}{lcccc}
\hline Species & Sampling & Dates & Averaging Period & Concentration \\
\hline OC & filter collection & May 27-July 20 & $80 \mathrm{~h}$ & $56 \pm 27$ \\
EC & filter collection & May 27-July 20 & $80 \mathrm{~h}$ & $7 \pm 5 \mathrm{ng} \mathrm{m}^{-3}$ \\
WSOC & filter collection & May 27-July 20 & $80 \mathrm{~h}$ & $\mathrm{ng} \mathrm{m}^{-3}$ \\
PM $_{0.1-1.0}$ & OPC & May 28-July 18 & $1 \mathrm{~min}$ & $52 \pm 23$ \\
$\sigma_{\text {ap }}$ & PSAP & May 28-July 18 & minutes to hours & $266 \pm 243$ \\
\hline
\end{tabular}

and $\mathrm{EC}$ detection, one filter was processed for only $\mathrm{OC}$ and EC while the second ambient filter was used to detect WSOC. After WSOC extraction, the sample volume was filtered through a pre-fired quartz fiber filter and measured for organic carbon using a Sievers 900 carbon analyzer. Atmospheric field blanks were found to contribute negligibly to $\mathrm{OC}$ and $\mathrm{EC}$, but the combination of field blank and ultrapure water yielded detectable WSOC (averaging $61 \mu \mathrm{g} \mathrm{L}^{-1}$ and translating to $9-15 \mathrm{ng} \mathrm{m}^{-3}$ in terms of ambient concentrations) that was used to correct ambient sample WSOC concentrations. It should be noted that OC and WSOC samples may have artifacts associated with the sampling and laboratory procedures, such as a negative artifact associated with an increase in temperature prior to laboratory analysis. However, the extent to which the carbonaceous aerosol measurements are impacted by artifacts is currently unknown and thus the reported values of carbonaceous species should be considered as operationally defined.

[9] Optical atmospheric measurements included particulate absorption $\left(\sigma_{\mathrm{ap}}\right)$ using a Particle Soot Absorption Photometer (PSAP), and particle size-resolved number count using a LASAIR optical particle counter (OPC). The PSAP operates by accumulating particles on an internal filter and detecting a gradual LED $(\lambda=565 \mathrm{~nm})$ transmittance drop with time. The absorption value was calculated for each transmittance drop of $0.3 \%$, yielding sample times ranging from minutes to hours. The calculation of $\sigma_{\mathrm{ap}}$ was via the Beer-Lambert law and adjusted with an empirical manufacturer calibration found to properly correct for filter media biases at transmittance levels $>0.7$, also setting the calculated light absorption values to a wavelength of $550 \mathrm{~nm}$ [Bond et al., 1999]. The LASAIR instrument measures particle number concentration in a series of size bins: $0.1-0.2 \mu \mathrm{m}, 0.2-0.3 \mu \mathrm{m}, 0.3-0.4 \mu \mathrm{m}, 0.4-0.5 \mu \mathrm{m}, 0.5-$ $0.7 \mu \mathrm{m}, 0.7-1.0 \mu \mathrm{m}$, and $1.0-2.0 \mu \mathrm{m}$. These data were used to approximate $\mathrm{PM}_{0.1-1.0}$, assuming a diameter at the midpoint of each size bin and a particle density of $1.5 \mathrm{~g} \mathrm{~cm}^{-3}$.

[10] Surface snow samples, representing the top $1-3 \mathrm{~cm}$ of snow, were collected throughout the field campaign for the analysis of water-soluble organic carbon (WSOC), water-insoluble organic carbon (WIOC), and elemental carbon (EC). The sample collection, processing, and analysis have been previously discussed [Hagler et al., 2007]. In short, WSOC samples ( $\sim 250 \mathrm{~mL}$ of snow) were collected on a $24 \mathrm{~h}$ frequency early in the season, increasing to consistently sampling every $4-6 \mathrm{~h}$ starting on 12 June 2006 . Duplicates or triplicates were taken at each sample collection. WIOC and EC samples $(\sim 10 \mathrm{~L}$ of snow) were collected at 17:00 (local time, UTC-2) each day, with duplicates collected every 3rd day. Filtration through a quartz fiber filter (Pall Corp: \#2500 QAT-UP, $25 \mathrm{~mm}$ ) was used as the operationally defined split between WSOC and
WIOC. Although the filters are rated at a nominal pore size of $700 \mathrm{~nm}$, past research indicates that the tortuous path through the filters may impart higher than $95 \%$ particle collection for $>100 \mathrm{~nm}$ particles [Ducret and Cachier, 1992; Lavanchy et al., 1999]. After passing the melted snow sample through the filter, WSOC was detected by a Sievers carbon analyzer employing UV oxidation. WIOC and EC were collected by vacuum-filtration through a quartz fiber filter, dried for $\sim 12 \mathrm{~h}$ under a clean hood, and later analyzed using the NIOSH thermal/optical transmittance (TOT) method [Birch and Cary, 1996].

\section{Results and Discussion}

\subsection{Atmospheric Concentrations and Transport}

[11] A summary of atmospheric OC, EC, WSOC, $\sigma_{\text {ap }}$, and $\mathrm{PM}_{0.1-1.0}$ is provided in Table 1, with a time series representing over 50 days of sampling shown in Figure 1. Additional information provided in Figure 1 includes plots of the particle number concentration and the estimated origin of the sampled air mass as determined by clustering 10-day back-trajectories. Isobaric 10-day back-trajectories were calculated for each sampling day and clustered with the Hybrid Single-Particle Lagrangian Integrated Trajectory (HYSPLIT) model [Draxler and Rolph, 2003] using FNL reanalysis data of the NCEP/GDAS meteorological model output. With the exception of one day (10 June 2006), all sampling days were fit to four clusters, with the clustered mean trajectories shown in Figure 2. The majority $(81 \%)$ of sampling days had 10-day trajectories constrained to the area near the Greenland Ice Sheet (cluster 2) or from the northeastern part of North America (cluster 1), with only a few sampling days represented by longer trajectories arriving from over Alaska (cluster 3) or the Asian continent (cluster 4). Our findings agree with prior results from a long-term analysis of 10-day back-trajectories reaching Summit, Greenland that observed summertime trajectories to have generally shorter paths and a large fraction (46\%) to originate over North America [Kahl et al., 1997].

[12] Filter-based concentrations during the first four measurement periods (representing 27 May 2006 to 18 June 1006) were high enough to allow for duplicate measurement of OC and EC. Duplicates were found to be very close for OC (averaging $8 \mathrm{ng} \mathrm{m}^{-3}$ or $11 \%$ ) but had higher difference for EC (averaging $4 \mathrm{ng} \mathrm{m}^{-3}$ or $36 \%$ ). Given that OC makes up the majority $(\sim 90 \%)$ of the particulate carbon mass measured at Summit, a small difference in the analytical split point between $\mathrm{OC}$ and $\mathrm{EC}$ for two duplicates results in a magnified change in EC. WSOC duplicates were found to be within close range (averaging $1 \mathrm{ng} \mathrm{m}^{-3}$ or $2 \%$ ), although variability in blanks contributes to higher uncertainty (2$3 \mathrm{ng} \mathrm{m}^{-3}$ or contributing $2-17 \%$ uncertainty dependent on the sample concentration). WSOC constitutes a large frac- 


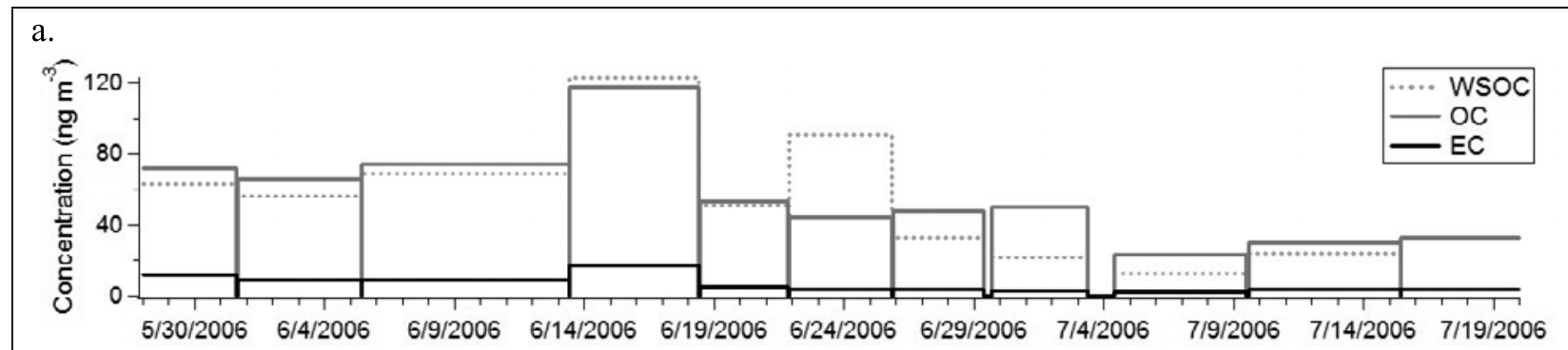

b.

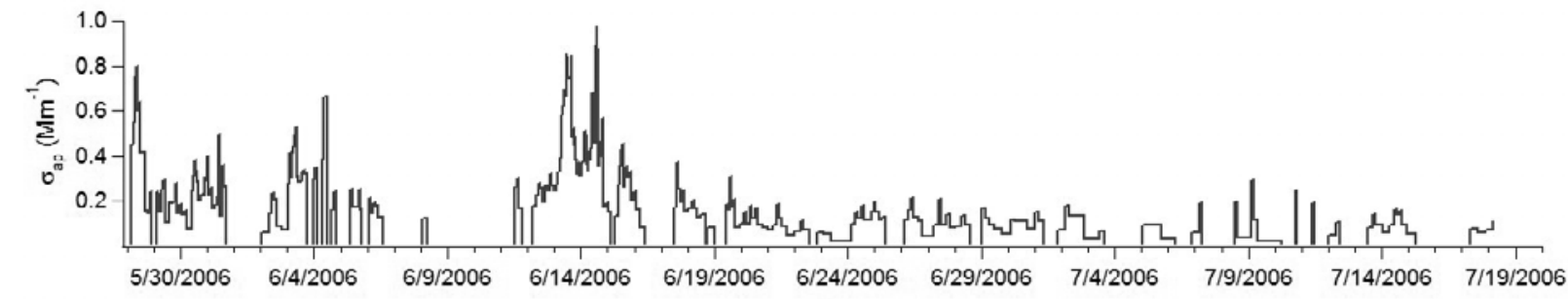

c.

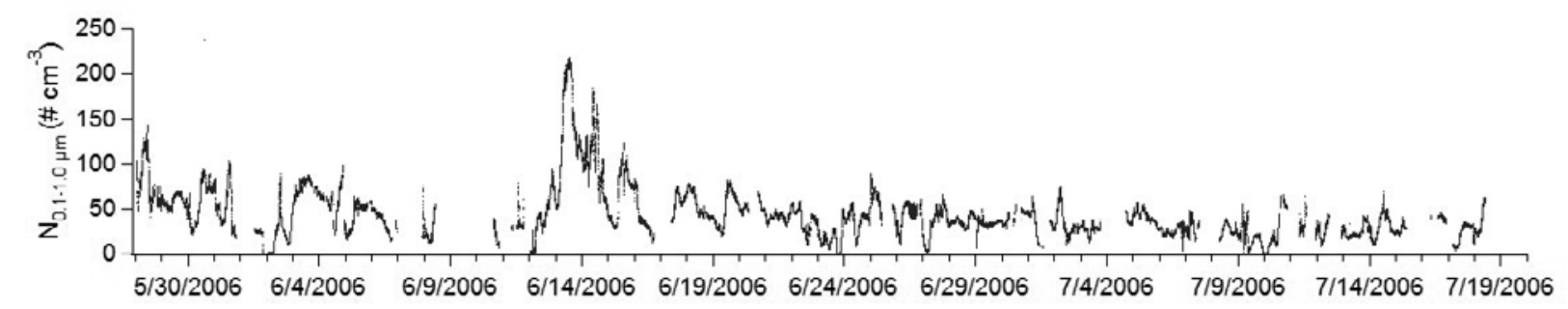

d.

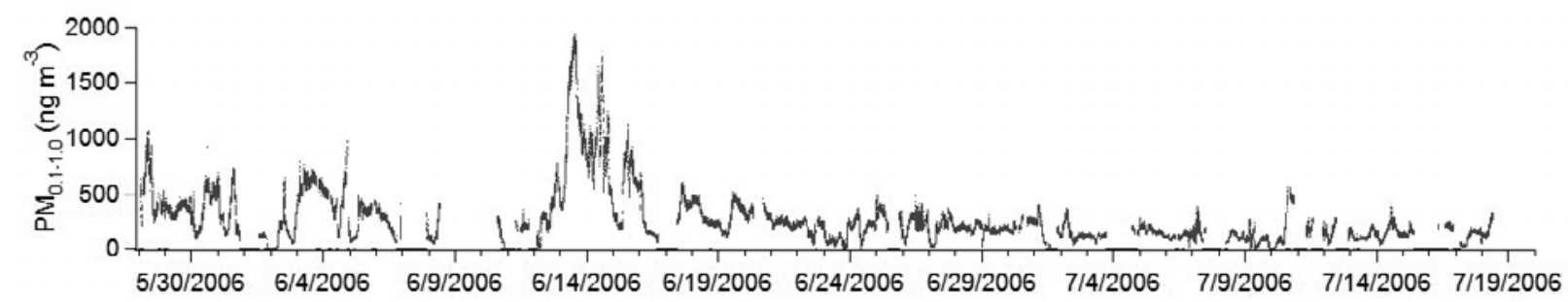

e.

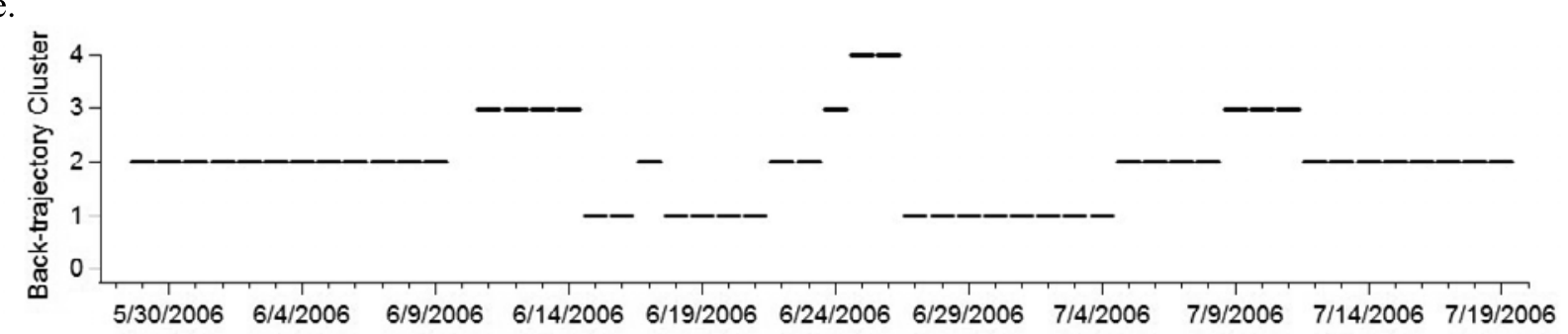

Figure 1. A time series of particulate measurements in the atmosphere of Summit, Greenland during Summer 2006, including carbonaceous particulate matter (a), the absorption coefficient (b), number concentration (c), $\mathrm{PM}_{0.1-1.0}(\mathrm{~d})$, and each sampling day's associated back-trajectory cluster (e).

tion of the particulate OC (Figure 1a). While the fifth sampling period (initiated late on 21 June 2006) has WSOC values within range of other atmospheric samples, the WSOC/OC fraction is far greater than 1.0 and outside of the uncertainty estimated in the measurement. It is expected that there may have been either an underestimation of OC or overestimation of WSOC, with WSOC contamination also a possible issue for this sample. Excluding this time period, it is seen that WSOC constitutes, on average, $81 \pm 20 \%$ of OC in Summit carbonaceous particulate matter. For the first three periods, where WSOC and OC were measured directly from the same filter and duplicates were available, WSOC/ OC has an even higher average of 0.89 and the duplicates have a WSOC/OC average agreement of 0.08 . 


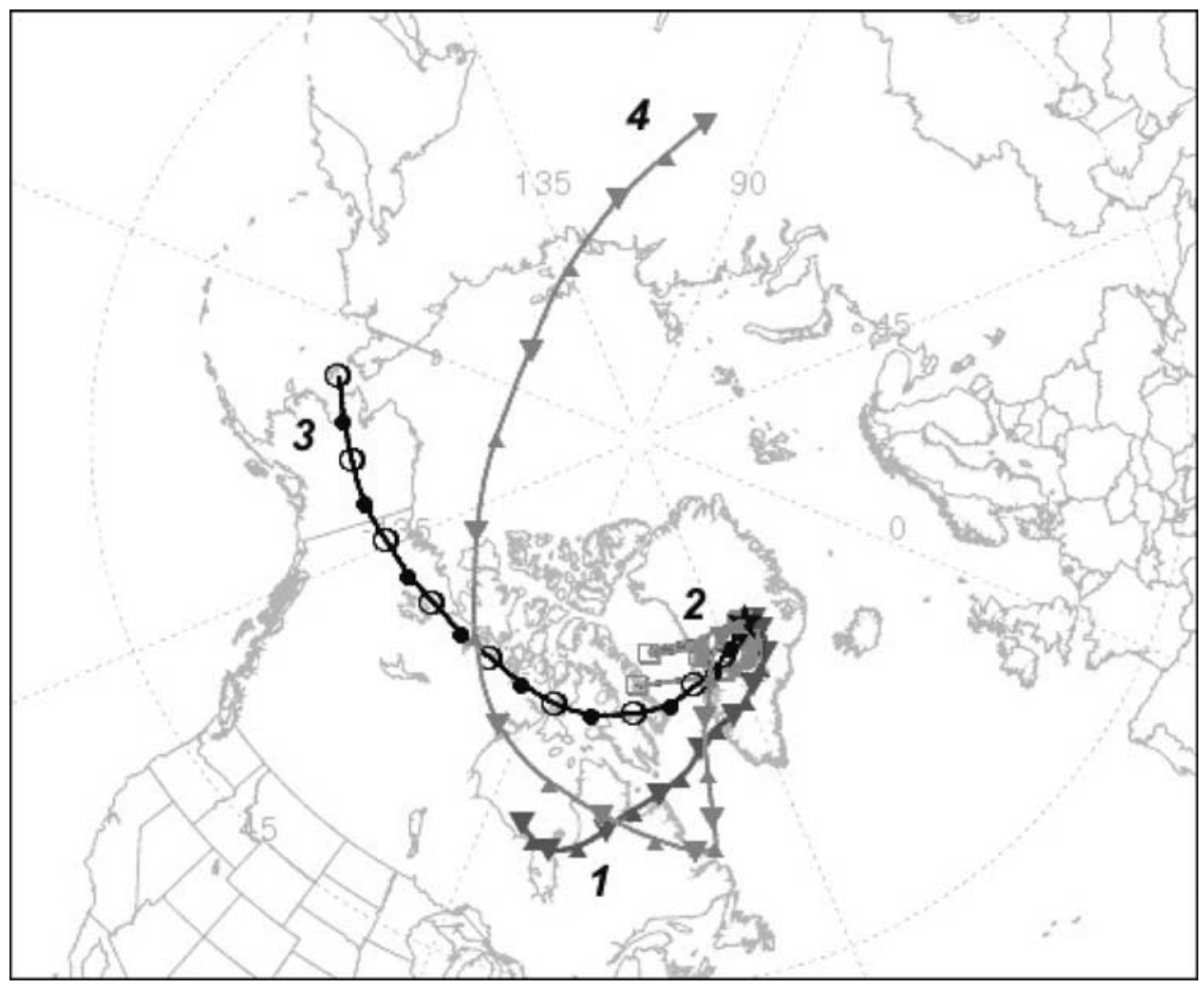

Figure 2. Clustered 10-day back trajectories for 28 May to 19 July. Each cluster contains a varying number of sampling days, with $27 \%$ of the days in cluster \#1, 54\% in cluster \#2, 15\% in cluster \#3, and $4 \%$ in cluster \#4.

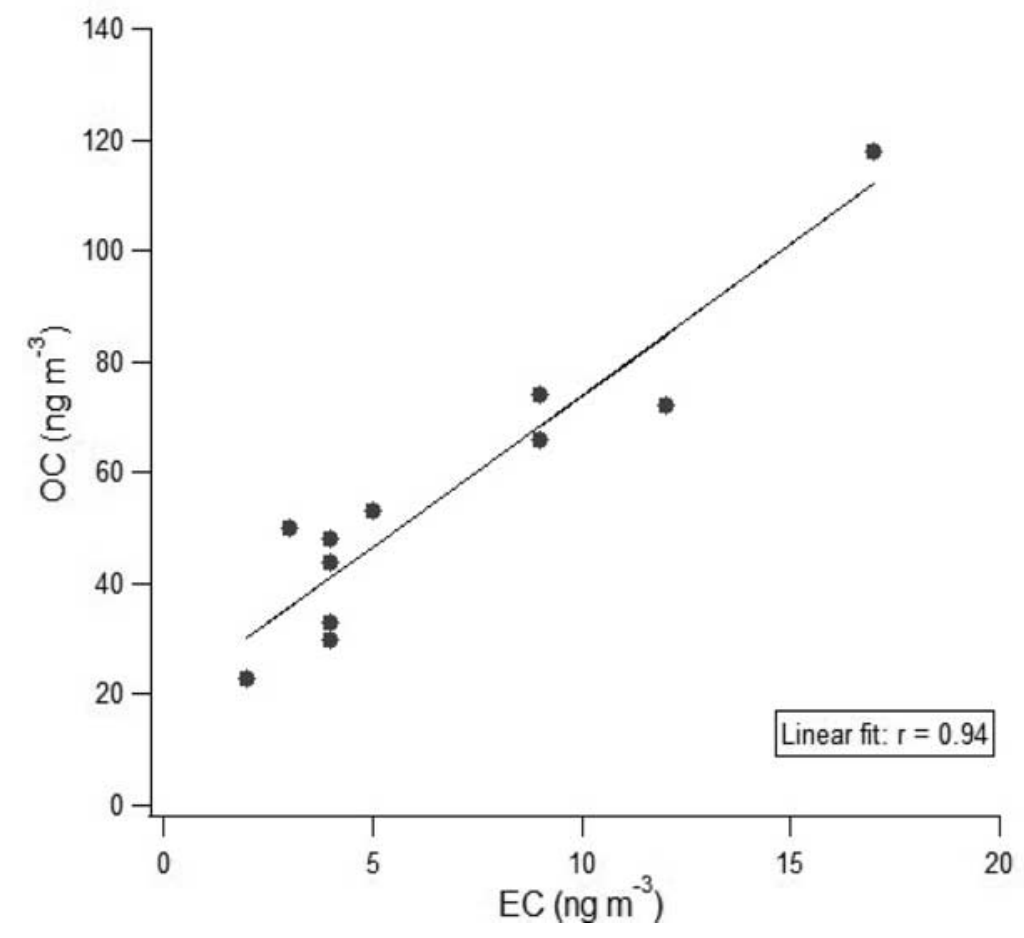

Figure 3. Relationship between atmospheric elemental carbon (EC) and organic carbon (OC). 


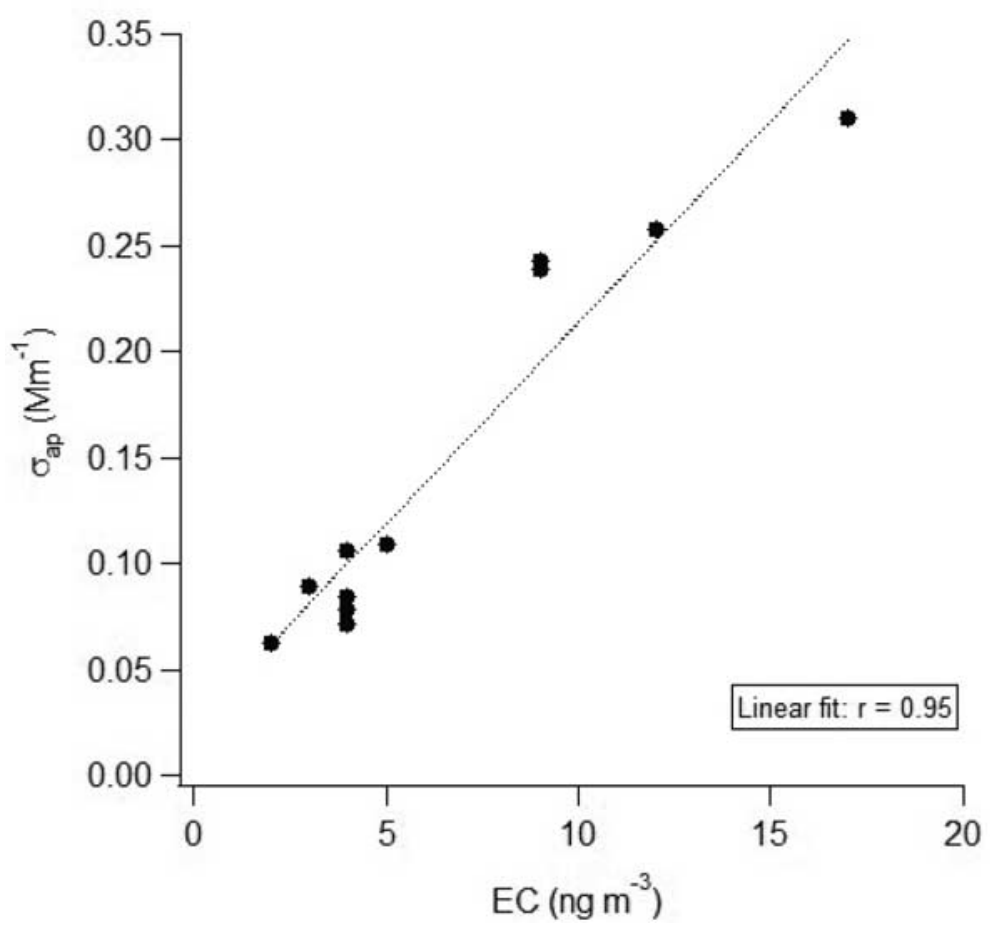

Figure 4. Relationship between atmospheric elemental carbon (EC) and the absorption coefficient $\left(\sigma_{\text {ap }}\right)$.

[13] To our knowledge, no prior Summit data is available to directly compare with our measured levels of atmospheric particulate OC, WSOC, and EC. However, measurements made using the same collection and analytical methods are available for other locations in the Northern Hemisphere and may add perspective to our results. The OC, WSOC, and EC values determined for Summit, Greenland were much less than the $211 \mathrm{ng} \mathrm{m}^{-3}, 123 \mathrm{ng} \mathrm{m}^{-3}$, and $20 \mathrm{ng} \mathrm{m}^{-3}$, respectively, observed using identical measurement techniques at a remote high altitude (3345 m) site on Niwot Ridge in the Colorado Rocky Mountains in January, 2006 (Hagler et al., unpublished results). Given the high altitude and mountainous nature of Niwot Ridge, it is likely that concentrations at this location represent the free troposphere. Past research indicates that Summit, Greenland also receives an input of the free troposphere, although surface inversions may modulate concentrations [Dibb, 2007; Helmig et al., 2007]. In addition to the absolute concentration comparison, the WSOC/OC ratio in Colorado was 0.52 on average, much lower than average WSOC/OC observed at Summit, Greenland. The WSOC/OC at Summit, Greenland was also much higher than past measurements reported in urban areas, such as Tokyo, Japan (monthly average WSOC/OC of $0.20-$ 0.35) [Miyazaki et al., 2006] and St. Louis, USA (monthly average WSOC/OC of 0.31-0.64) [Sullivan et al., 2004]. Both studies used similar analytical techniques as this research, although modified for higher frequency sampling. The substantially higher WSOC/OC observed at Summit, Greenland suggests the oxidation of primary organic carbon aerosol during transport and/or the significant contribution of secondary organic aerosol to particulate carbon mass. This result also suggests that water-based collection of WSOC (such as a mist-chamber or Particle-Into-Liquid
Sampler) would be well-suited for the study of particulate OC on the Greenland Ice Sheet. Finally, it is useful to compare measured carbonaceous aerosol values to previously reported concentrations of major aerosol ions at Summit. Comparing with summer-long sampling at Summit in 1993 for major ions, it can be seen that our measured OC and $\mathrm{EC}$ values are in a similar range of past reported values for sulfate and nitrate of $402 \mathrm{ng} \mathrm{m}^{-3}$ and $26 \mathrm{ng} \mathrm{m}^{-3}$, respectively [Bergin et al., 1995b].

[14] Atmospheric OC and EC appear to be very highly correlated $(r=0.94)$, indicating common sources and/or source locations (Figure 3). However, the OC/EC ratio $(10 \pm 3)$ did vary over the course of sampling, possibly due to differences in origin and processing during transport. Some variability in the OC/EC ratio is also likely attributed to uncertainty in measuring EC (duplicate samples had OC/ EC ratios agree within 40\%). Given the strong relationship with EC and a highly water-soluble nature, particulate $\mathrm{OC}$ at Summit appears to be a product of oxidized primary organic carbon and gas-to-particle conversion of combustion emissions. Past research has also described a secondary nature of particulate OC at Summit during a Canadian biomass burning event in 1994, reporting enhanced levels of particulate carboxylates at Summit relative to that of fresh biomass burning emissions [Dibb et al., 1996]. Additionally, while concurrent hourly sampling for particulate and gasphase OC found evidence of gas/particle partitioning impacting $\mathrm{OC}$ concentrations (Anderson et al., unpublished results), the high correlation found in our filter-based measurement between $\mathrm{OC}$ and $\mathrm{EC}$ suggests that the multiday integrated filter samples preserved the broader signal of emissions transported to the Greenland Ice Sheet. 


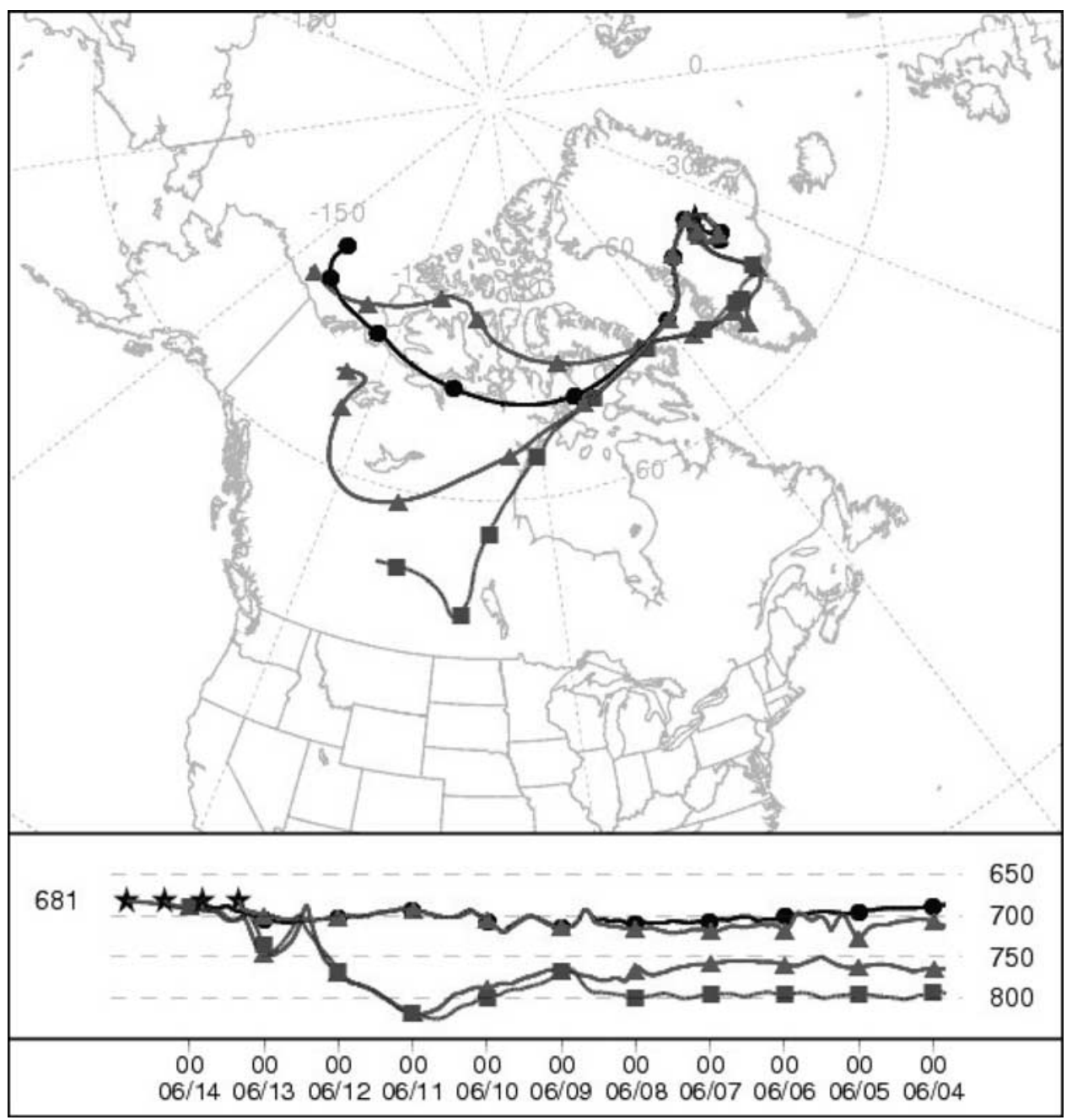

Figure 5. 10-day back-trajectories and pressure altitude $(\mathrm{hPa})$ during the high particulate matter concentrations observed on 13-14 June. Air parcel pathways are marked every $24 \mathrm{~h}$.

[15] After averaging $\sigma_{\text {ap }}$ over the extended filtering time periods, an extremely high correlation was observed between the $\sigma_{\text {ap }}$ and EC $(\mathrm{r}=0.95)$ (Figure 4). Dividing timesynchronized $\sigma_{\mathrm{ap}}$ by $\mathrm{EC}$ results in an average estimated mass absorption cross-section $\left(\mathrm{E}_{\mathrm{ap}}\right)$ of $24 \mathrm{~m}^{2} \mathrm{~g}^{-1}$. Equivalently, assuming a black carbon (BC) absorption crosssection of $10 \mathrm{~m}^{2} \mathrm{~g}^{-1}(\lambda=565 \mathrm{~nm})$ leads to BC/EC slope of 2.4. The observed $E_{a p}$ at Summit is similar to the $18.3 \mathrm{~m}^{2} \mathrm{~g}^{-1}$ found in Atlanta, Georgia using identical measurement techniques [Carrico et al., 2003]. However, as observed in the Atlanta study [Carrico et al., 2003] and described in a recent review of light absorbing carbon [Bond and Bergstrom, 2006], the estimation of $\mathrm{E}_{\mathrm{ap}}$ varies depending on the technique used to estimate EC mass. In addition, it is possible that other absorbing species besides EC, such as dust or absorbing organics, can contribute to the absorption value.

[16] The time period of June 13-14 stands out for the significant sustained increase observed in every measured atmospheric aerosol property (Figure 1). During the filter sampling period covering most of this episode (1318 June), OC and EC are higher than their summertime averages by $113 \%$ and $158 \%$, respectively. Given that the integrated filter sampling did not perfectly line up with the high concentration episode, this is likely an underestimate of the actual increase. The higher frequency measurement of $\sigma_{\text {ap }}$ and $\mathrm{PM}_{0.1-1.0}$ found levels during June $13-14$ at $197 \%$ and $290 \%$ higher than their summertime averages, respectively. Given that EC and $\sigma_{\text {ap }}$ were seen to greatly increase, it is expected that some form of combustion emissions were

Table 2. Measured Snow-Phase Species at Summit, Greenland During Summer 2006

\begin{tabular}{lccccc}
\hline Species & Measurement & Dates & Frequency & Concentration & Units \\
\hline WSOC & UV-oxidation & 31 May-20 July & $4-24 \mathrm{~h}$ & $111.1 \pm 45.5$ & $\mu \mathrm{g} \mathrm{kg}^{-1}$ \\
WIOC & Thermal/optical & 29 May-20 July & $24 \mathrm{~h}$ & $11.9 \pm 7.1$ & $\mu \mathrm{g} \mathrm{kg}^{-1}$ \\
EC & Thermal/optical & 29 May-20 July & $24 \mathrm{~h}$ & $0.6 \pm 0.4$ & $\mu \mathrm{g} \mathrm{kg}^{-1}$ \\
\hline
\end{tabular}


a.

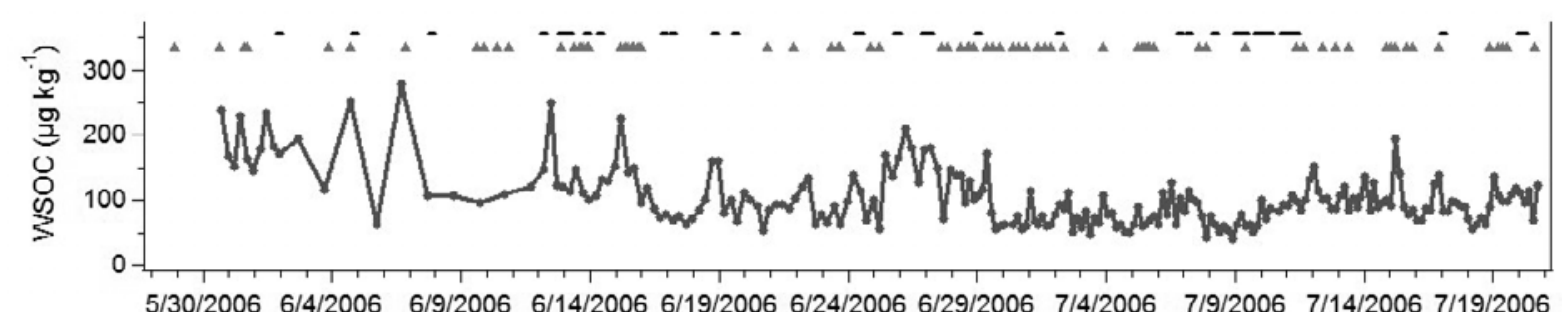

b.

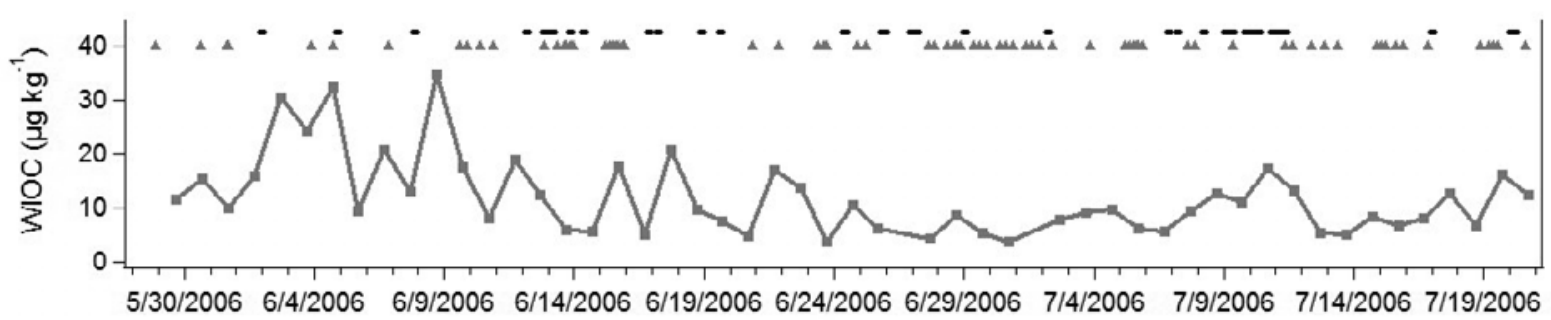

c.

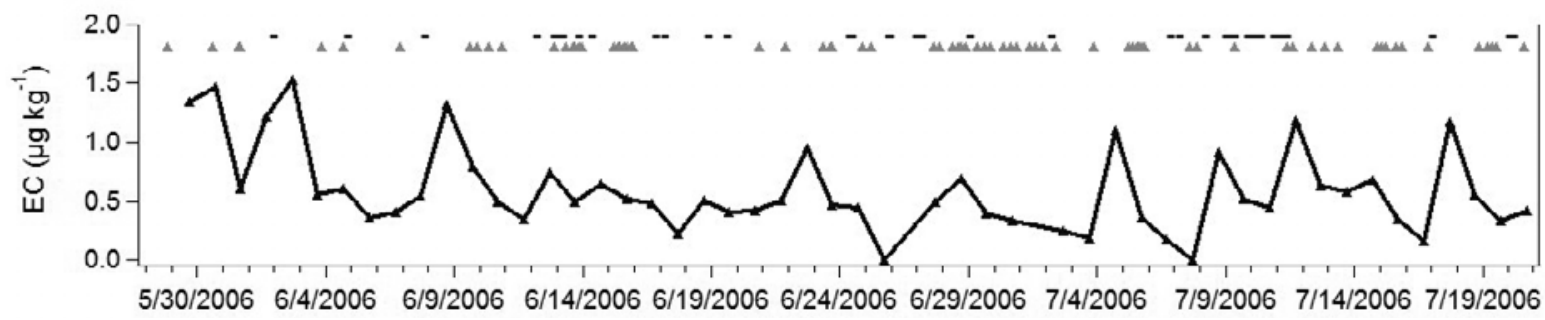

Figure 6. A time series of snow-phase water-soluble organic carbon (a), water-insoluble organic carbon (b), and elemental carbon (c). Observations of snow (triangle markers) and fog (dash markers) are indicated.

transported to Summit, Greenland. The air mass pathways are displayed in Figure 5, with HYSPLIT-calculated trajectories displayed starting every $12 \mathrm{~h}$. It appears that the air mass tracked a path from northern Alaska/northwestern Canada. Fire records from Canada [Canadian Forest Service, 2006] indicate that active fires $(63,000+$ hectares in Canada) were occurring during the time period when back-trajectories passed over the region. In general, this high concentration event along with similar episodes measured previously [e.g., Stohl et al., 2006] suggest that distant sources are capable of causing substantial multiday increases in ambient carbonaceous particulate matter in the atmosphere over the Greenland Ice Sheet.

\subsection{Snow Concentrations}

[17] The average snow-phase concentration of watersoluble organic carbon (WSOC), water-insoluble organic carbon (WIOC), and elemental carbon (EC) have been previously discussed to compare with a 3-meter snow pit and are provided in Table 2 for reference [Hagler et al., 2007]. In addition, a time series of the measured surface snow concentrations are presented in Figure 6, as well as precipitation (snowfall and fog) as noted during each of our snow sample collections and including weather logs from science technicians at the research site. On average, duplicates $(\mathrm{N}=18)$ for WIOC and EC in the surface snow were within $40 \%\left(3.5 \mu \mathrm{g} \mathrm{kg}^{-1}\right)$ and $36 \%\left(0.1 \mu \mathrm{g} \mathrm{kg}^{-1}\right)$, respectively. The frequently collected duplicates $(\mathrm{N}=216)$ for WSOC were, on average, within $34 \%\left(29.1 \mu \mathrm{g} \mathrm{kg}^{-1}\right)$.

[18] Concentrations of all snow-phase carbonaceous species (WSOC, WIOC, and EC) are observed to vary throughout the summer, with precipitation events appearing to occur either immediately prior or during spikes in concentrations (Figure 6). However, it should be noted that the occurrence of snowfall or fog does not always lead to a concentration spike in surface snow concentrations. As discussed in a model developed to link atmospheric and snow concentrations of aerosol species [Bergin et al., 1995a], a number of factors impact the wet deposition flux of particulate species to snow, including the current atmospheric particulate matter concentration and the properties of each snow/fog event (scavenging ratio, duration, intensity, and atmospheric height).

[19] Unlike the prominent maxima observed in atmospheric particulate matter concentrations during 13-14 June, WSOC, WIOC, and EC are found to have their individual maximum concentrations roughly a week prior. For high WIOC and EC concentrations occurring on 2nd June and 
8th June, it is interesting to note that fog appears to be the dominant wet deposition mechanism. Surface snow WSOC also appears to have concentration spikes associated with fogs, with major increases on June 12th and June 18th occurring after isolated fog episodes (i.e., no snowfall had occurred for several days). Previous research has also found fog-based deposition to be important in the flux of ions to the Greenland Ice Sheet [Bergin et al., 1995b]. Snowfall, in isolation from fog episodes, also appears to contribute to higher surface snow concentrations, such as on June 15th (WSOC, WIOC), July 4th (EC), and July 15 th (WSOC). It is of note that even the maximum EC concentration measured during the summer time series $\left(1.5 \mu \mathrm{g} \mathrm{kg}^{-1}\right)$ would equate to only a small $(<1 \%)$ decrease in surface albedo [Warren and Wiscomb, 1985]. Assuming the low EC levels measured at Summit well-represent the remainder of the Greenland Ice Sheet, it appears that snow-phase EC has only a minor influence on local climate.

[20] Given the small snow volume $(250 \mathrm{~mL})$ needed for WSOC measurement, higher frequency (every 4-6 h) WSOC sampling was consistently performed starting 12 June 2006 and provides information on concentration changes on a shorter time basis. One major observation is that WSOC concentrations did appear to vary on a 4-6 h time basis (Figure 6). In addition, precipitation events (in particular, fog) mostly occurred during the coldest part of the day (approximately between 23:00 - 06:00 local time) and led to frequent WSOC spikes in the early morning. For example, on 15-16 July, WSOC was measured to be $95 \mu \mathrm{g} \mathrm{kg}^{-1}$ at 17:00 (15th July), rising to a maximum of $195 \mu \mathrm{g} \mathrm{kg}^{-1}$ at 05:00 (16th July), and then dropping to $90 \mu \mathrm{g} \mathrm{kg}^{-1}$ by 17:00 (16th July). If measuring only at 17:00, an undulation of $\sim 100 \mu \mathrm{g} \mathrm{kg}^{-1}$ (>100\% increase and drop off) would have been missed. Considering the variability among WSOC duplicates $\left(\sim 34 \%\right.$ or $\left.29 \mu \mathrm{g} \mathrm{kg}^{-1}\right)$, this $\sim 100 \mu \mathrm{g} \mathrm{kg}^{-1}$ concentration increase/decrease appears to represent a real concentration change that occurred on a sub- $24 \mathrm{~h}$ time basis.

[21] As pointed out in our recent analysis of a 3-meter snow pit [Hagler et al., 2007], there is a likelihood that the surface snow WIOC and WSOC concentrations measured are influenced by photochemical processes. In addition, temperature-dependent air-snow partitioning may also play a substantial role in modifying snow-phase concentrations of organics, particularly that of WSOC. Given that precipitation events often coincide with low temperatures, it is difficult to separate the ensuing decrease of concentrations by photochemical degradation and temperature-dependent partitioning. One simple comparison is to look at several days with and without the occurrence of wet deposition. Looking at the sampling period with continuous 4-h sampling (27 June 2006-20 July 2006), a 24-h dry period occurred over 17:00 July 2nd-17:00 July 3rd. WSOC was found to oscillate from a minimum of $48 \mu \mathrm{g} \mathrm{kg}^{-1}$ to $82 \mu \mathrm{g} \mathrm{kg}^{-1}$ (difference of $34 \mu \mathrm{g} \mathrm{kg}^{-1}$ ). Another 24-h period without precipitation was 17:00 July 13th-17:00 July 14th, where WSOC varied from a minimum of $90 \mu \mathrm{g} \mathrm{kg}^{-1}$ to a maximum of $136 \mu \mathrm{g} \mathrm{kg}^{-1}$ (difference of $46 \mu \mathrm{g} \mathrm{kg}^{-1}$ ). Finally, the longest stretch of time with no precipitation took place during 05:00 July 17th-17:00 July 18th, where snow concentrations ranged from 57 to $99 \mu \mathrm{g} \mathrm{kg}^{-1}$ (difference of $42 \mu \mathrm{g} \mathrm{kg}^{-1}$ ). For all periods of time, no consistent diurnal pattern in WSOC concentration was observed. Given that some concentration change may be due to spatial variability in surface snow concentrations and our inability to precisely collect the identical layer of surface snow (i.e., WSOC duplicate difference of $29.1 \mu \mathrm{g} \mathrm{kg}^{-1}$ ), it is suggested that the average value of $\pm 41 \mu \mathrm{g} \mathrm{kg}^{-1}$ is an upper limit on the impact of air-snow temperature-dependent partitioning on WSOC concentrations.

[22] Looking in detail at a few days with precipitationlinked concentration spikes may provide insight into the impact of post-depositional processes. For example, an evening fog occurred on June 25 th, with maximum surface snow concentrations $\left(211 \mu \mathrm{g} \mathrm{kg}^{-1}\right)$ observed following the fog event and then dropping by $40 \%$ to $127 \mu \mathrm{g} \mathrm{kg}^{-1}$ within the following $8 \mathrm{~h}$. Another example is July 15th, which had a maximum WSOC concentration after snowfall of $195 \mu \mathrm{g} \mathrm{kg}^{-1}$ and then fell by $54 \%$ to $90 \mu \mathrm{g} \mathrm{kg}^{-1}$ within the next $8 \mathrm{~h}$. That the change in concentration for both days was significantly greater than $41 \mu \mathrm{g} \mathrm{kg}^{-1}$ points to a factor outside of temperature-dependent air-snow partitioning causing a net loss in surface snow concentrations. At this point it is difficult to determine whether the greater loss is due to outgassing of freshly deposited snow/fog or linked to post-depositional processes. Our past analysis [Hagler et al., 2007] comparing WSOC in surface snow to aged summer layers in a snow pit found substantial loss in the snowpack record, likely due to photochemical processes, but the timescale of this loss is yet uncertain.

[23] In addition to the apparent net loss of organic compounds from the snowpack, it may be possible that photochemical processing may cause a transfer of organic mass from WSOC to WIOC or vice versa. To investigate the possible transfer between carbon fractions, 24-h concentration change was calculated for WSOC and WIOC for each sampling day $\left(\triangle \mathrm{WSOC}=\mathrm{WSOC}_{\mathrm{t}+1}-\mathrm{WSOC}_{\mathrm{t}}\right)$. As WSOC was sampled at a higher frequency, only samples taken at 17:00 (simultaneous with WIOC samples) were included in this analysis. Plotted in Figure 7, the majority of cases fall into the first (positive $\triangle \mathrm{WSOC}$, positive $\triangle \mathrm{WIOC}$ ) and third quadrant (negative $\triangle \mathrm{WSOC}$, negative $\triangle \mathrm{WIOC}$ ). Only a few cases $(\sim 9)$ have opposing change in WSOC and WIOC, and even fewer cases having opposing change exceeding sampling uncertainty. In addition, there is a wide degree of scatter and in a number of cases, one species changes substantially while the other has zero change in concentration. Overall, it appears that the relationship between WSOC and WIOC is weak. However, it should be noted that this analysis is hindered by the fact that only a 24-h change is available for analysis and it is likely that any evening/morning concentration spikes from wet deposition may have already been substantially processed by the time of WIOC and EC sample collection at 17:00.

\subsection{Comparison of Air and Snow}

[24] While it is highly interesting to directly compare our measured time series of carbonaceous species in the air and snow, a number of caveats need to be taken into consideration prior to making conclusions. First, our atmospheric measurements were either shut off or were filtered for time periods potentially impacted by camp emissions. Unfortunately, there is no possible sector control system to prevent emissions from impacting snow concentrations. Next, while we used identical filter media and analytical instrumentation 


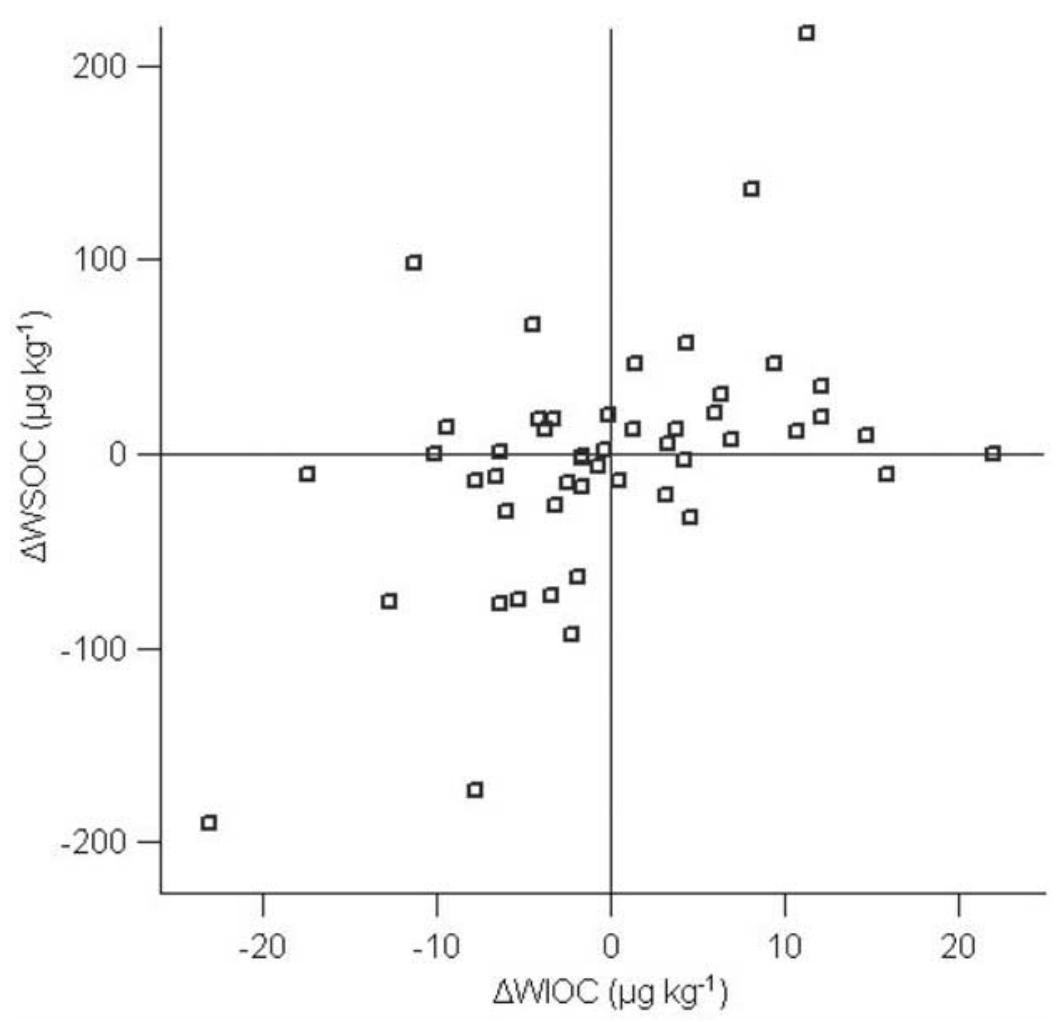

Figure 7. 24-h change in surface snow WSOC compared with 24-h change in surface-snow WIOC.

in processing atmospheric and snow-phase WSOC, WIOC, and EC, there are fundamental differences in the air and snow sampling techniques. All atmospheric filter samples were collected downstream of a $\mathrm{PM}_{2.5}$ cyclone and WSOC was extracted off of the filters. For snow-phase samples, liquid filtration through a quartz-fiber filter was used to separate insoluble species (WIOC and EC) and soluble species (WSOC) prior to analysis. Finally, probably the most significant caveat is that snow concentrations are highly dependent on deposition events (dry or wet) and related factors affecting the magnitude of flux to snow [Bergin et al., 1995a, 1995b] as well as the potential occurrence of post-depositional processing.

[25] Despite the numerous hurdles to overcome in interpreting air versus snow concentrations, there may still be useful information in the comparison. The high-frequency snow-phase sampling of WSOC is compared with atmospheric $\mathrm{PM}_{0.1-1.0}$ that was averaged over identical time periods (Figure 8). In a number of periods, it appears that snow-phase WSOC increases while $\mathrm{PM}_{0.1-1.0}$ decreases (e.g., June 15th, June 18th, and 22nd June). However, the trend is inconsistent, with some major spikes in snow-phase WSOC (e.g., June 12th and July 16th) occurring with no simultaneous decrease in $\mathrm{PM}_{0.1-1.0}$. As mentioned earlier and observed in recent measurements of gas-phase OC above the Greenland Ice Sheet (Anderson et al., unpublished results), snow concentrations of WSOC may also be influenced by a temperature-based partitioning of gaseous organics to the snow.

[26] Assuming for a moment that all snow-phase particulate matter is derived from deposited atmospheric particulate matter, it would be expected that the carbon balance between the various carbon species (WSOC, WIOC, EC) would be similar in the air and snow. However, it appears that this is not the case, as atmospheric WIOC and EC was at an approximate 1:2 ratio compared with 20:1 in snow (Figure 9). This may suggest that WIOC is formed in the snow through polymerization of water-soluble organic molecules. However, the enhanced WIOC relative to EC in the snow may also be linked to other factors, such as preferential deposition or differences between air/snow measurement. Additionally, total $\mathrm{OC}$ to $\mathrm{EC}$ in the atmosphere is

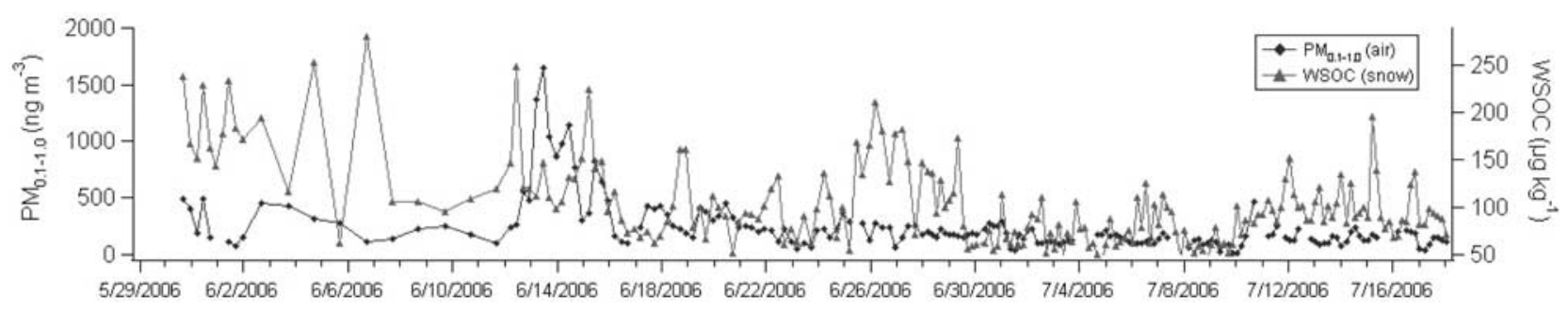

Figure 8. Comparison of atmospheric $\mathrm{PM}_{0.1-1.0}$ concentrations versus surface snow WSOC. 


$$
\square \text { WSOC } \mathbb{W} \text { WIOC } \quad \mathrm{EC}
$$

Air filters

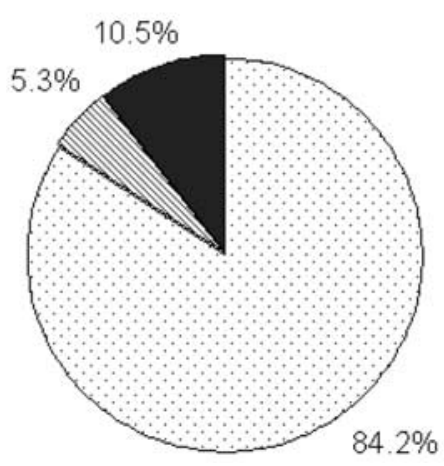

Surface snow

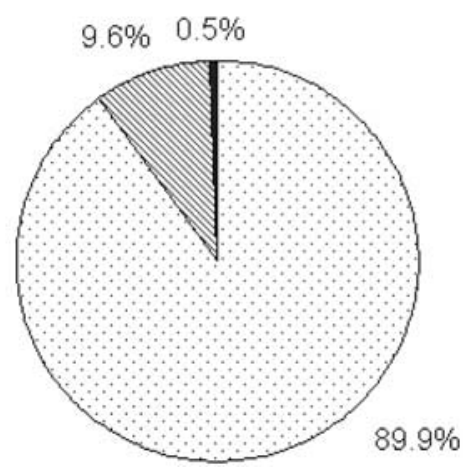

Figure 9. Carbon balance of particulate species in the atmosphere and of particulate and water-soluble species in the surface snow.

roughly $10: 1$ while in the surface snow it is 205:1. Similar to the high total OC/EC ratio observed in the 3-meter snow pit [Hagler et al., 2007], it appears that the surface snow concentrations do not mimic atmosphere levels. While there are numerous reasons for expected differences in the air and snow concentrations, the extreme enhancement of organics (WSOC and WIOC) in the snowpack supports the idea that gaseous organics are a significant source of OC in snow.

\section{Summary and Concluding Remarks}

[27] During the summer of 2006, carbonaceous particulate matter and related particulate optical properties were measured in the air and snow on the Greenland Ice Sheet. It is of note that EC and $\sigma_{\text {ap }}$ were detectable and highly correlated throughout the entire summer, illustrating the ever-present input of combustion emissions to the atmosphere above the Greenland Ice Sheet. EC was also wellcorrelated with atmospheric OC, suggesting similar sources and/or source locations. Atmospheric OC was found to be much more water-soluble ( $81 \%$ on average) than at lessremote locations in the Northern Hemisphere, which may be due to either the oxidation of primary OC during transport and/or gas-to-particle formation of secondary OC. Highest atmospheric concentrations were observed during June 1314 , with the near-real-time measurement of $\sigma_{\text {ap }}$ and $\mathrm{PM}_{0.1-}$ 1.0 levels $197 \%$ and $290 \%$ higher than their summertime averages. Back-trajectory modeling revealed this air mass was transported from over Alaska/northwest Canada, with active forest fires occurring in Canada as a possible source of carbonaceous particulates.

[28] Surface snow sampling (WIOC, EC, and WSOC) at time increments ranging from 4-24 h found time-varying surface concentrations of all species. It was interesting that the more frequent sampling of WSOC found significant concentration change occurring on a sub- $24 \mathrm{~h}$ time basis. In particular, it appears that wet-deposition-associated concentration spikes in WSOC had substantial loss occur within $8 \mathrm{~h}$, possibly due to outgassing and/or photochemical processes. Thus it is possible that the daily measurements of WIOC and EC may not represent the true variability of carbonaceous particulates in the snow. In general, it appears that carbonaceous species in the surface snow do not closely track atmospheric concentrations, with major atmospheric events not uniformly observed in the snow. It is likely that a number of factors contribute to the mismatch between the time series in the air and snow, such as temporally variable wet deposition (fog and snow), differences in the collection of air versus snow, and the possible occurrence of postdepositional processes. In addition to the differences in the air and snow time series, it appears that the summer average WSOC/WIOC/EC carbon balance in the snow has much higher $\mathrm{OC}$ (WSOC + WIOC) relative to $\mathrm{EC}$ than in the atmosphere. In light of the apparent loss occurring in snowphase $\mathrm{OC}$, the high $\mathrm{OC}$ to $\mathrm{EC}$ ratio in the snow is unexpected and suggests that gaseous organics are an important source of snow-phase OC.

[29] Acknowledgments. This project was funded by the National Science Foundation and through graduate fellowships to the author (G.H.) from the American Association of University Women and P.E.O. International. We are very grateful for the planning and field support provided by our research colleagues, Casey Anderson and Rob Griffin of the University of New Hampshire and Jamie Schauer, Erika von Schneidemesser, and Martin Shafer of the University of WisconsinMadison. Finally, this research project would not have been possible without the hard work of the Veco Polar Resources staff servicing Summit Camp or the air transit provided by the New York Air National Guard 109th Airlift Wing.

\section{References}

Bergin, M. H., et al. (1995a), A simple model to estimate atmospheric concentrations of aerosol chemical species based on snow core chemistry at Summit, Greenland, Geophys. Res. Lett., 22, 3517-3520.

Bergin, M. H., et al. (1995b), The contributions of snow, fog, and dry deposition to the summer flux of anions and cations at Summit, Greenland, J. Geophys. Res., 100, 16,275-16,288.

Birch, M. E., and R. A. Cary (1996), Elemental carbon-based method for monitoring occupational exposures to particulate diesel exhaust, Aerosol Sci. Technol., 25, 221-241.

Bond, T. C., and R. W. Bergstrom (2006), Light absorption by carbonaceous particles: An investigative review, Aerosol Sci. Technol., 40, 27-67.

Bond, T. C., et al. (1999), Calibration and intercomparison of filter-based measurements of visible light absorption by aerosols, Aerosol Sci. Technol., $30,582-600$.

Canadian Forest Service (2006), Forest Fire in Canada. (http://fire. cfs.nrcan.gc.ca/report/archives_e.php, accessed 5/16/2007) 
Carrico, C. M., et al. (2003), Urban aerosol radiative properties: Measurements during the 1999 Atlanta Supersite Experiment, J. Geophys. Res., 108(D7), 8422, doi:10.1029/2001JD001222.

Chylek, P., and U. Lohmann (2005), Ratio of the Greenland to global temperature change: Comparison of observations and climate modeling results, Geophys. Res. Lett., 32, L14705, doi:10.1029/2005GL023552.

Clarke, A. D., and K. J. Noone (1985), Soot in the Arctic snowpack - A cause for perturbations in radiative-transfer, Atmos. Environ., 19, 2045-2053.

Currie, L. A., et al. (2005), Long range transport of biomass aerosol to Greenland: Multi- spectroscopic investigation of particles deposited in the snow, J. Radioanal. Nucl. Chem., 263, 399-411.

Dassau, T. M., et al. (2002), Investigation of the role of the snowpack on atmospheric formaldehyde chemistry at Summit, Greenland, J. Geophys. Res., 107(D19), 4394, doi:10.1029/2002JD002182.

Dibb, J. E. (2007), Vertical mixing above Summit, Greenland: Insights into seasonal and high frequency variability from the radionuclide tracers ${ }^{7} \mathrm{Be}$ and ${ }^{210} \mathrm{~Pb}$, Atmos. Environ., 41, 5020-5030.

Dibb, J. E., and M. Arsenault (2002), Shouldn't snowpacks be sources of monocarboxylic acids?, Atmos. Environ., 36, 2513-2522.

Dibb, J. E., et al. (1994), Soluble acidic species in air and snow at Summit, Greenland, Geophys. Res. Lett., 21, 1627-1630.

Dibb, J. E., et al. (1996), Biomass burning signatures in the atmosphere and snow at Summit, Greenland: An event on 5 August 1994, Atmos. Environ., 30, 553-561.

Draxler, R. R., and G. D. Rolph (2003), HYSPLIT (HYbrid Single-Particle Lagrangian Integrated Trajectory) Model access via NOAA ARL READY Website (http://www.arl.noaa.gov/ready/hysplit4.html, accessed 5/21/2007), NOAA Air Resources Laboratory, Silver Spring, MD.

Ducret, J., and H. Cachier (1992), Particulate carbon content in rain at various temperate and tropical locations, J. Atmos Chem., 15, 55-67.

Ford, K. M., et al. (2002), Studies of peroxyacetyl nitrate (PAN) and its interaction with the snowpack at Summit, Greenland, J. Geophys. Res., 107(D10), 4102, doi:10.1029/2001JD000547.

Hagler, G. S. W., et al. (2007), Particulate and water-soluble carbon measured in recent snow at Summit, Greenland, Geophys. Res. Lett., 34, L16505, doi:10.1029/2007GL030110.

Hansen, J., and L. Nazarenko (2004), Soot climate forcing via snow and ice albedos, Proc. Natl. Acad. Sci. U. S. A., 101, 423-428.

Helmig, D., et al. (2007), What is causing high ozone at Summit, Greenland?, Atmos. Environ., 41, 5031-5043.

Hutterli, M. A., et al. (1999), Atmosphere-to-snow-to-firn transfer studies of HCHO at Summit, Greenland, Geophys. Res. Lett., 26, 1691-1694.

Jacobi, H. W., et al. (2002), Measurements of hydrogen peroxide and formaldehyde exchange between the atmosphere and surface snow at Summit, Greenland, Atmos. Environ., 36, 2619-2628.

Jacobi, H. W., et al. (2004), Reactive trace gases measured in the interstitial air of surface snow at Summit, Greenland, Atmos. Environ., 38, 1687 1697.
Jaffrezo, J. L., et al. (1993), Transfer-function of polycyclic aromatichydrocarbons from the atmosphere to the polar ice.1. Determination of atmospheric concentrations at Dye-3, Greenland, Atmos. Environ. Part A-General Topics, 27, 2781-2785.

Jaffrezo, J. L., et al. (1998), Biomass burning signatures in the atmosphere of central Greenland, J. Geophys. Res., 103, 31,067-31,078.

Kahl, J. D. W., et al. (1997), Air mass trajectories to Summit, Greenland: A 44-year climatology and some episodic events, J. Geophys. Res., 102, $26,861-26,875$.

Kerminen, V. M., et al. (1998), The physicochemical structure of the Greenland summer aerosol and its relation to atmospheric processes, J. Geophys. Res., 103, 5661-5670.

Lavanchy, V. M. H., et al. (1999), Historical record of carbonaceous particle concentrations from a European high-alpine glacier (Colle Gnifetti, Switzerland), J. Geophys. Res., 104, 21,227-21,236.

Lim, H. J., and B. J. Turpin (2002), Origins of primary and secondary organic aerosol in Atlanta: Results of time-resolved measurements during the Atlanta supersite experiment, Environ. Sci. Technol., 36, 4489-4496.

Miyazaki, Y., et al. (2006), Time-resolved measurements of water-soluble organic carbon in Tokyo, J. Geophys. Res., 111, D23206, doi:10.1029/ 2006JD007125.

Roberts, D. L., and A. Jones (2004), Climate sensitivity to black carbon aerosol from fossil fuel combustion, J. Geophys. Res., 109, D16202, doi:10.1029/2004JD004676.

Schauer, J. J., et al. (1996), Source apportionment of airborne particulate matter using organic compounds as tracers, Atmos. Environ., 30, $3837-$ 3855.

Simoneit, B. R. T., et al. (1999), Levoglucosan, a tracer for cellulose in biomass burning and atmospheric particles, Atmos. Environ., 33, $173-$ 182.

Stohl, A., et al. (2006), Pan-Arctic enhancements of light absorbing aerosol concentrations due to North American boreal forest fires during summer 2004, J. Geophys. Res., 111, D22214, doi:10.1029/2006JD007216.

Sullivan, A. P., et al. (2004), A method for on-line measurement of watersoluble organic carbon in ambient aerosol particles: Results from an urban site, Geophys. Res. Lett., 31, L13705, doi:10.1029/2004GL019681.

Swanson, A. L., et al. (2002), Photochemically induced production of $\mathrm{CH} 3 \mathrm{Br}, \mathrm{CH} 3 \mathrm{I}, \mathrm{C} 2 \mathrm{H} 5 \mathrm{I}$, ethene, and propene within surface snow at Summit, Greenland, Atmos. Environ., 36, 2671-2682.

Twohy, C. H., et al. (1989), Light-absorbing material extracted from cloud droplets and its effect on cloud albedo, J. Geophys. Res., 94, 8623-8631.

Warren, S. G., and W. J. Wiscomb (1985), Dirty snow after nuclear war, Nature, 313, 467-470.

M. H. Bergin, G. S. W. Hagler, and E. A. Smith, School of Civil and Environmental Engineering, Georgia Institute of Technology, Atlanta, GA 30332, USA. (gswhagler@gmail.com)

J. E. Dibb, Climate Change Research Center, Institute for the Study of Earth, Oceans, and Space, University of New Hampshire, Durham, NH 03824, USA. 